\title{
Investigating Cytotoxic Effects of Juniperus Excelsa Extract on Esophageal Cancer Cell Line KYSE-30 and Normal Fibroblast Cell Line HU02
}

Ameneh Elikaei (PhD)

Department of Microbiology, Faculty of Biological Sciences, Alzahra University, Tehran, Iran

Hossein Vazini(PhD)

Department of Nursing, Faculty of Basic Sciences, Hamedan Branch, Islamic Azad University, Hamedan, Iran

Fatemeh Javani Jouni(PhD) Department of Microbiology, Islamic Azad University, Tehran North Branch, Tehran, Iran

Jaber Zafari(PhD)

Department of Microbiology, Islamic Azad University, Tehran North

Branch, Tehran, Iran

Corresponding author: Ameneh Elikaei

Tel: +989126398037

Email: arezoo_elikaei774@yahoo.com

Address: Department of

Microbiology, Faculty of Biological

Sciences, Alzahra University, Tehran, Iran

Received: 18 Jul 2018

Revised: 02 Aug 2018

Accepted: 06 Aug 2018

\section{(c) (1) (8)}

This work is licensed under a Creative

Commons Attribution 4.0 License.

\section{ABSTRACT}

Background and objectives: Esophageal cancer is the eighth most common type of cancer in the world. Considering the adverse effects of anticancer drugs and the emergence of chemotherapy resistance, plantderived extracts and their constituents could be a valuable source of novel anticancer drugs. In this study, we investigated cytotoxic effects of Juniperus excelsa leaf extract on esophageal cancer cell line KYSE-30 and healthy fibroblast cells (HU02 cells).

Methods: KYSE-30 cells and HU02 cells were cultured in DMEM medium. The cells were treated with different concentrations (1, 10, 100, $500 \mu \mathrm{g} / \mathrm{ml}$ ) of the $J$. excelsa leaf extract for 24 and 40 hours. The cytotoxic effects of the extract were assessed using the MTT assay. Data were analyzed using SPSS (version 19) and GraphPad Prism 5.

Results: According to results of the MTT assay, the Juniperus excelsa's leaf extract exerted significant cytotoxic effects on esophagus cancer cell line (KYSE-30) and healthy fibroblast cells (HU02) in a timeand dose-dependent manner $(\mathrm{P}<0.05)$.

Conclusion: The J. excelsa leaf extract has cytotoxic effects against KYSE-30 esophageal cancer cells while causing lesser toxicity on healthy fibroblast cells. 0ur findings suggest that the potential anticancer effects of this extract should be further exploited in future studies.

Keywords: Cytotoxic, MTT, Hu02, Kyse-30, Juniperus excelsa.

This paper should be cited as: Elikaei A, Vazini H, Javani Jouni F, Zafari J [Investigating Cytotoxic Effects of Juniperus Excelsa Extract on Esophageal Cancer Cell Line KYSE-30 and Normal Fibroblast Cell Line HU02]. mljgoums. 2019; 13(5): 13-18 


\section{INTRODUCTION}

Esophageal cancer (EC) is the eighth most common type of cancer and the sixth cause of cancer deaths in the world (1). According to the reports of the World Health Organization (WHO), nearly 400,000 people die of EC every year (1). About 51,000 cancer cases are diagnosed in Iran every year, of which 6500 cases are affected by EC (3). The two most common forms of esophageal cancer are squamous cell carcinoma and adenocarcinoma with a 5-year survival rate of less than 10\% (4). Factors including opium and narcotic drugs use, acid reflux, drinking alcohol and hot beverages, vegetarianism, selenium deficiency, viral and Helicobacter infections and genetic susceptibility are considered as risk factors of EC (5). Given the adverse effects of anticancer drugs and the emergence of chemotherapy resistance, much emphasis has been put on discovering novel complementary and alternative therapies with less side effects and a high therapeutic efficacy (6-7). Evidence suggests that some secondary metabolites of plants may be an incredible source of compounds with potential anticancer effects (8). Juniperus excelsa is a coniferous plant from the Cupressaceae family that grows wild in Asia (9). The leaf of this plant is rich in monoterpene hydrocarbons such as $\alpha$-pinene, $\beta$-pinene, myrcene, sabinene, limonene, ethyl acetate, $\beta$-carotene and flavonoids (9). The plant has been used in traditional medicine for wound/scars healing and treatment of edema, kidney disease, rheumatism, ulcerative colitis, toothache, etc. (9-11). To investigate the potential anticancer properties of this plant, we investigated the cytotoxic effects of $J$. excelsa extract on an EC cell line (KYSE-30) and normal fibroblast cells (HU02).

\section{MATERIALS AND METHODS}

Both cell lines were bought from the cell bank of the Pasteur Institute of Iran (Tehran, Iran). Dulbecco's Modified Eagle Medium (DMEM) and fetal bovine serum (FBS) were obtained from Gibco (USA), and 3-(4,5-dimethylthiazol-2-yl)-2,5-

diphenyltetrazolium bromide (MTT) was bought from Merck (Germany). Two $\mathrm{kg} J$. excels leaves and twigs were collected from Bandar Abbas (Iran) in April 2016. Once rinsed, the leaves and twigs were shade-dried at room temperature and then powdered using an electric mill. Next, the plant powder was mixed with $250 \mathrm{ml}$ of pure methanol on a shaker for 24 hours, at $40-50{ }^{\circ} \mathrm{C}$. The mixture was passed through a Whatman filter paper and then placed in a rotary evaporator. The obtained extract was passed through a Whatman filter paper and then poured in a special essence container. To prepare a concentration range, the extract was diluted with various volumes of the medium without serum. After being passed through a Millipore filter (pore diameter of $0.22 \mu \mathrm{m}$ ), the prepared concentrations of the extract were stored in a refrigerator until use. KYSE-30 and HU02 cells were cultured in a T25 flask containing DMEM with $10 \% \mathrm{FBS}, 100 \mu \mathrm{g} / \mathrm{ml}$ penicillin and $100 \mu \mathrm{g} / \mathrm{ml}$ streptomycin (Gibco, Germany). The flask was incubated at $37{ }^{\circ} \mathrm{C}$, $5 \% \mathrm{CO}_{2}$ and in $95 \%$ humidity for 4 hours. The cells were passaged twice and were trypsinized. A cell suspension $\left(10^{4}\right.$ cells $\left./ \mathrm{ml}\right)$ was prepared and poured in wells of a 96microwell plate. Later, various concentrations $(1,10,100$, and $500 \mu \mathrm{g} / \mathrm{ml})$ of the $J$. excelsa extract were added to each well. The microplate was incubated at $37{ }^{\circ} \mathrm{C}$ for 24 and 48 hours (Figure 1). Cytotoxic effects of the extract on KYSE-30 and HU02 cells and the optimum concentration of the extract were evaluated using the MTT assay. The assay relies on the reduction of MTT, a yellow water-soluble tetrazolium dye, primarily by mitochondrial dehydrogenases, to purple colored formazan crystals (12). There is a direct relationship between the produced formazan crystals and the population of live cells.

After 24 and 48 hours of incubation, supernatant was discarded and $100 \mu \mathrm{l}$ of DMEM medium containing $100 \mathrm{mg} / \mathrm{ml}$ MTT solution were added to each well. The microplate was incubated for 4 hours at $37^{\circ} \mathrm{C}$, $5 \% \mathrm{CO}_{2}$ and in $95 \%$ humidity. After 5 to 10 minutes, supernatant was discarded and absorbance at $540-690 \mathrm{~nm}$ was read by an ELISA reader (Emax ${ }^{\circledR}$ Endpoint). This experiment was repeated five times. The half maximal inhibitory concentration $\left(\mathrm{IC}_{50}\right)$ was calculated using the GraphPad Prism 5 software. Data were analyzed by SPSS software (version 19) using two-way ANOVA and Bonferroni correction. Data were expressed as mean \pm standard deviation. Pvalues less than 0.05 were considered as statistically significant. 


\section{RESULTS}

Based on the results of the MTT assay, the mean $\mathrm{IC}_{50}$ of the $J$. excelsa extract against KYSE-30 cancer cells was $118.5 \mu \mathrm{g} / \mathrm{ml}$ after 24 hours and $21.85 \mu \mathrm{g} / \mathrm{ml}$ after 48 hours. Increasing the incubation time from 24 hours to 48 hours significantly increased the inhibitory effects of the extract against these cells $(\mathrm{P}<0.05)$. After 24 hours of incubation, concentrations of $1,10,100$ and $500 \mu \mathrm{g} / \mathrm{ml}$ of the extract exerted cytotoxic effects on $97.57 \%, 88.04 \%, 68.92 \%$ and $57.97 \%$ of the KYSE-30 cells, respectively. After 48 hours, the extract at concentrations of 1, 10, 100 and $500 \mu \mathrm{g} / \mathrm{ml}$ showed cytotoxic effects on $97.03 \%, 77.18 \%, 66.56 \%$ and $53.87 \%$ of the KYSE-30 cells, respectively (Figure 2). Furthermore, the mean $\mathrm{IC}_{50}$ of the $J$. excelsa extract against HU02 fibroblast cells was $77.05 \mu \mathrm{g} / \mathrm{ml}$ after 24 hours and $9.82 \mu \mathrm{g} / \mathrm{ml}$ after 48 hours. Increasing the incubation time from 24 hours to 48 hours significantly increased the inhibitory effects of the extract against these cells $(\mathrm{P}<0.05)$. After 24 hours of incubation, the extract at concentrations of 1 , 10,100 and $500 \mu \mathrm{g} / \mathrm{ml}$ showed cytotoxic effects on $93.35 \%, 82.81 \%, 63.11 \%$ and $39.22 \%$ of the fibroblast cells (HU02 cells), respectively. After 48 hours, concentrations of $1,10,100$ and $500 \mu \mathrm{g} / \mathrm{ml}$ of the extract exerted cytotoxic effects on $91.05 \%, 70.63 \% 45.90 \%$ $30.52 \%$ of HU02 cells (Figure 3 and Table 1). The results show that increasing the concentration of the extract significantly decreases the number of viable cells $(\mathrm{P}<0.05)$.

\footnotetext{
Figure 1- Esophageal cancer cell line (KYSE-30) and healthy fibroblast cells (HU02) before and after treatment with the Juniperus excelsa extract. (A): HU02 cells before treatment with the extract, (B): HU02 cells after the treatment, $(C)$ : KYSE-30 cells before the treatment, and (D): KYSE-30 after the treatment.
}

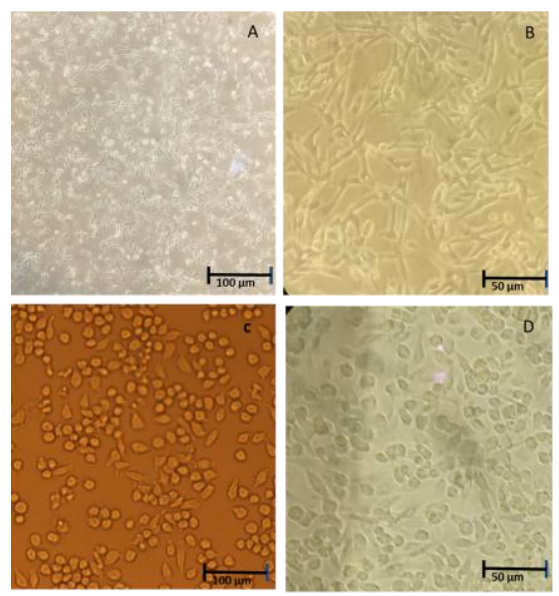

Figure 2- Inhibitory effects of the $J$. excelsa extract on KYSE-30 esophageal cancer cells after 24 and 48 hours of incubation

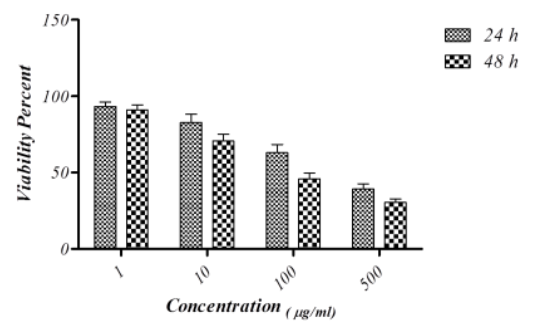

Figure 3- Inhibitory effects of the $J$. excelsa extract on normal human fibroblast cells (HU02) after 24 and 48 hours of incubation

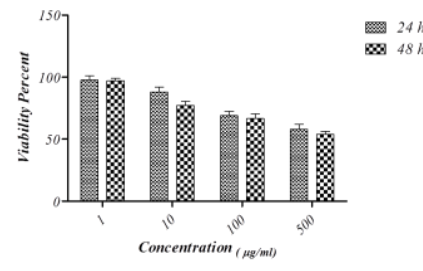


Table 1- Percentage viability of the KYSE-30 cancer cells and normal fibroblast cells (HU02) following 24 and 48 hours of incubation with various concentrations of the J. excelsa extract

\begin{tabular}{|c|c|c|c|c|}
\hline Cell type & $\begin{array}{c}\text { Concentration of extract } \\
(\mu \mathrm{g} / \mathrm{ml})\end{array}$ & Viability after $24 \mathrm{~h}$ & Viability after $48 \mathrm{~h}$ & P-value \\
\hline \multirow[t]{4}{*}{ Kys-30 } & 1 & $93.35 \pm 2.30$ & $91.05 \pm 2.30$ & $P>0.05$ \\
\hline & 10 & $82.81 \pm 12.18$ & $70.63 \pm 12.18$ & $P>0.05$ \\
\hline & 100 & $63.11 \pm 17.20$ & $45.90 \pm 17.20$ & $P>0.05$ \\
\hline & 500 & $39.22 \pm 8.69$ & $30.52 \pm 8.69$ & $P>0.05$ \\
\hline \multirow[t]{4}{*}{ Hu02 } & 1 & $97.57 \pm 9.53$ & $97.03 \pm 9.53$ & $P>0.05$ \\
\hline & 10 & $88.04 \pm 10.86$ & $77.18 \pm 10.86$ & $P>0.05$ \\
\hline & 100 & $68.92 \pm 2.36$ & $66.56 \pm 2.36$ & $P>0.05$ \\
\hline & 500 & $57.97 \pm 4.09$ & $53.87 \pm 4.09$ & $P>0.05$ \\
\hline
\end{tabular}

\section{DISCUSSION}

Numerous studies have been carried out on the medicinal properties of plants and their extracts (13-17). The potential favorable effects of such extracts could be attributed to the presence of compounds such as terpenes, flavonoids, polyphenols and other secondary metabolites in these extracts (8). Numerous studies have investigated the cytotoxic effects of various plant extracts and their constituents on different gastric and esophageal cancer cell lines. According to these studies, the cytotoxic effects of these compounds can be attributed to their high flavonoid and phenolic content and antioxidant properties (13-17). Another study showed that the water-soluble Cuminum cyminum extract has anticancer effects on human colon cancer cell line SW742 (18). In another study, low concentrations of Ecballium elaterium extract exhibited cytotoxic effects on KYSE-30 cells. In addition, this effect was increased by extending the incubation time (19). In a study on alcoholic extracts of Avocado's fruit and leaves, cytotoxic activity of the extract on esophageal cancer cells (KJSE cells) was attributed to the presence of phytochemicals, which inhibits cell growth by blocking intratumoral growth signals and increasing activity of intracellular oxygen radicals (20). In the present study, we evaluated the toxic and anticancer effects of the $J$. excels $a$ extract on KYSE-30 and HU02 cells. The mean $\mathrm{IC}_{50}$ of the $J$. excelsa extract against KYSE-30 cancer cells was $118.5 \mu \mathrm{g} / \mathrm{ml}$ after 24 hours and $21.85 \mu \mathrm{g} / \mathrm{ml}$ after 48 hours. Furthermore, the inhibitory effects of the extract were more notable against KYSE-30 cancer cells than against healthy fibroblast cells (HU02). A previous study reported that the $J$. excelsa extract have anti-proliferative and inhibitory effects against hepatoma cell line HepG2 (21).
In another study, the cytotoxic effects of the $J$. excelsa extract against human colon cancer cell line (LNCaP), KB-V (+VLB) and KB-V (- VLB) were attributed to the presence of diterpenes and sesquiterpenes (22). In another study, extracts of Juniperus foetidissima and Juniperus Sabina showed cytotoxic activity against HeLa cells. The extract of $J$. foetidissima also showed inhibitory effects on MDAMB468 (human breast adenocarcinoma) cells but not against KB (human epidermoid carcinoma) cells (23). Muto et al. revealed that Juniperus taxifolia leaf extract has cytotoxic effects against human leukemia cell line HL60 (24). In a study by Emami et al., extracts from $J$. foettidissima leaves and fruit exhibited antioxidant and anticancer activities (25). The extract from $J$. excelsa leaves is rich in monoterpene hydrocarbons, oxygencontaining monoterpenes, sesquiterpene, oxygen-containing sesquiterpene and flavonoids with antioxidant properties $(9,25)$. The antioxidant properties of flavonoids are exerted via complex formation with metal ions and activation of peroxisome proliferatoractivated receptors, which inhibits COX-2 expression and oxidation reactions in lipids and other molecules (14,26-29). Therefore, they can prevent cancer progression by disrupting biological activities that can negatively affect the control of cell cycle, cell proliferation and cell differentiation $(14,26-$ 29). The J. excelsa extract also contain $\alpha$ pinene and $\beta$-pinene that can exert antioxidant and proapoptotic effects and promote tumor suppressor activity by increasing the expression of P53 $(17,26)$. On the other hand, some polyphenolic antioxidants can interact with nitric oxide synthase (26) and disrupt mitochondrial respiratory chain, thereby increasing production of caspases 3,8 and 9 
and inducing apoptosis in cancer cells (12).

\section{CONCLUSION}

Our findings show that the $J$. excelsa can exert inhibitory effects against KYSE-30 cancer cells and healthy fibroblast cells in a time- and dose-dependent manner. However, the therapeutic potential of this extract for treatment of esophageal cancer requires further

\section{REFERENCES}

1. Akbari MR, Malekzadeh R, Nasrollahzadeh D, Amanian D, Sun P, Islami F, et al. Familial risks of esophageal cancer among the Turkmen population of the Caspian littoral of Iran. International journal of cancer. 2006; 119(5): 1047-51.

2. Stathopoulos G, Tsiaras N. Epidemiology and pathogenesis of esophageal cancer: management and its controversial results. Oncol Rep. 2003; 10(2): 449-54.

3. Sadjadi A, Nouraie M, Mohagheghi MA, MousaviJarrahi A, Malekezadeh R, Parkin DM. Cancer occurrence in Iran in 2002, an international perspective. Asian Pac J Cancer Prev. 2005; 6(3): 359-63.

4. Zhang L, Wu YD, Li P, Tu J, Niu YL, Xu CM, Zhang ST. Effects of cyclooxygenase-2 on human esophageal squamous cell carcinoma. World J Gastroenterol. 2011; 17(41): 4572-80. doi: 10.3748/wjg.v17.i41.4572.

5. Nouri Dalouyi M, Mahrerallnaghsh R, Sayyah MK. Molecular genetics and gene therapy in esophageal cancer: a review article. Tehran University Medical Journal. 2011; 69(6): 331-343. [Persian]

6. Pabla N, Murphy RF, Liu K, Dong Z. The copper transporter Ctrl contributes to cisplatin uptake by renal tubular cells during cisplatin nephrotoxicity. Am J Physiol Renal Physiol. 2009; 296(3): F505-11. doi: 10.1152/ajprenal.90545.2008.

7. Rabik CA, Dolan ME. Molecular mechanisms of resistance and toxicity associated with platinating agents. Cancer treatment reviews. 2007; 33(1): 9-23.

8. Kawashty SA, Mosharrata SAM, El-Gibali M, Saleh NAM. The flavonoids of four Pistacia species in Egypt. Biochem Syst Ecol. 2000; 28(9): 915-7.

9. Emami S.A, Abedindoa B.F , Hassanzadeh-Khayya M, Antioxidant Activity of the Essential Oils of Different Parts of Juniperus excelsa M. Bieb. Subsp. excelsa and J. excelsa M. Bieb. Subsp. polycarpos (K. Koch) Takhtajan (Cupressaceae). Iranian Journal of Pharmaceutical Research. 2011; 10 (4): 799-810. DOI: 10.22037/ijpr.2011.985.

10. Yesilada E, Honda G, Sezik E, Tabata M, Fujita T, et al. Traditional medicine in Turkey. V. Folk medicine in the inner Taurus Mountains. J. Ethnopharmacol. 1995; 46(3): 133-152.

11. Fujita T, Sezik E, Tabata M, Yesilada E, Honda G, Takeda Y. Traditional medicine in Turkey VIIl. Folk medicine in middle and west black sea regions. Econ. Bot. 1995; 49: 406-422.

12. Forouzandeh F, Salimi S, Naghsh N, Zamani N, Jahani S. Evaluation of anti-cancer effect of Peganum harmala $L$ hydroalcholic extract on human cervical carcinoma epithelial cell line (HeLa) Journal of Shahrekord University of Medical Sciences. 2014; 16(4): $1-8$. investigation.

\section{ACKNOWLEDGEMENTS}

We are thankful to the Alzahra

University.

\section{CONFLICT OF INTEREST}

The authors declare that there is no conflict of interest regarding the publication of this article.

13. Moheghil N, Tavakkol Afshari J, Brook A. The Cytotoxic Effect of Zingiber Afficinale in Breast Cancer Cell Line (MCF7) Ofogh-e-Danesh; Journal of Gonabad University of Medical Sciences. 2011; 17(4): 28-34. [Persian]

14. Meimandi K, yaghoobi MM. Effects of aqueous and ethanolic extract of Rosa damascena mill L.against human gastric Cancer cells, Journal of Molecular and Cellular Research (Iranian Journal of Biology). 2015; 28(2): 299-309. [Persian]

15. Behdarvand Shoushtar A, Sazgar H, Ghasemi Pirbaloti A. Investigating cytotoxic effect of hydroalcholich extract from combination of Kelussia odoratissma Mozaff and Satureja bachtiarica Bunge on Hela cancer cells line. Medical Sciences. 2017; 27(3): 178-186. [Persian]

16. Nejad Shahrokhabadi K, Tavakkol Afshari J, Rakhshandeh H, Barouk A. Study Of cytotoxicity effect of total saffron extract on hepatocarcinoma cell line (HepG2). Medical Sciences. 2009; 19(3): 154159.[Persian]

17. Seyedalipour B, Pourakbar E, Taravati A. The Cytotoxic Effect of Ethanolic Extract of Pistacia Khinjuk Leaf on HeLa and MCF-7 Cancerous Cell Lines. J RafsanjanUniv Med Sci. 2016; 14(11): 939-52. [Persian]

18. Zamanian Azodi M, Heydari Keshel S, Azizi Jalilian F. Evaluation of the Ctytotoxic Effect of Cuminum cyminum essential oils on Human Colon Cancer cell line SW742. sjimu. 2013; 20(5): 138-148.[Persian]

19. Bahluli Sh, Rostami R, Jahed Sh, Hossein Zadeh Sh. Investigating the antinociceptive effect of Ecballium Elaterium on the esophageal cell carcinoma cell line (KYSE-30). 11th Annual Conference of Iranian Pathology Society and 5th annual Cancer Society Congress, Tehran, Iran. October 2009; 28-30.

20. Vahedi Larijani L, Ghasemi M, Abediankenari S, Naghshvar F, Azadbakht M, Yazdani Cherati J, et al. The Study of the Effects of Four Avocado Extracts in Esophagus Squamous Cell Carcinoma. J Mazand Univ Med Sci. 2013; 23(2): 48-54. [Persian]

21. Khabbaz Azar S, Moeen MR, Niknahad $H$. Cytotoxicity of Juniperus excels and Salvia mirzayanii Extracts against HepG2 Cells. Iranian Journal of Pharmaceutical Sciences Autumn. 2012; 8(4): 241-247.

22. Topcu G, Erenler R, Cakmak O, Johansson CB, Celik C, Chai HB, Pezzuto JM. Diterpenes from the berries of Juniperus excelsa. Phytochemistry. 1999; 50(7):1195-9. 
23. Sadeghi-aliabadi H, Emami A, Saidi M, Sadeghi B, Jafarian A. Evaluation of In Vitro Cytotoxic Effects of Juniperus foetidissima and Juniperus sabina Extracts Against a Panel of Cancer Cells. Iranian Journal of Pharmaceutical Research. 2009; 8(4): 281-286. DOI: 10.22037/ijpr.2010.823.

24. Muto N, Tomokuni $\mathrm{T}$, Haramoto $\mathrm{M}$, Tatemoto $\mathrm{H}$,Nakanishi $\mathrm{T}$, Inatomi $\mathrm{Y}$, et al. Isolation of apoptosisand differentiation-inducing substances toward human promyelocytic leukemia HL-60 cells from leaves of Juniperus taxifolia. Biosci Biotechnol Biochem. 2008; 72(2):477-84.

25. Emami SA, Asili J, Mohagheghi Z, Hassanzadeh MK. Antioxidant activity of leaves and fruits of Iranian conifers. Ecam. 2007; 4(3): 313-9.

26. Hotta M, Nakata R, Katsukawa M, Hori K, Takahashi S, Hiroyasu I. Carvacrol, a component of thyme oil, activates PPAR $\alpha$ and $\gamma$ and suppresses cox- 2 expression. J Lipid Res. 2010; 51(1): 132-9. doi: 10.1194/jlr.M900255-JLR200.
27. Kris-Etherton PM, Hecker KD, Bonanome A, Coval $\mathrm{SM}$, Binkoski AE, Hilpert KF. Bioactive compounds in foods:their role in the prevention of cardiovascular disease and cancer. AM J MED. 2002; 113(Suppl 9): 7188.

28. Kumaran A, Karunakaran RJ. Antioxidant and free radical scavenging activity of an aqueous extract of Coleus aromaticus. Food Chem. 2006; 97(1): 109-114.

29. Pokorny J. Are Natural Antioxidants etter and Safer than Synthetic Antioxidant Components. Eur J Lipid Sci Technol. 2007; 109(9): 629-42. DOI: 10.1002/ejlt.200700064. 